\title{
Chemistry Preservation with CCB of Timber Fence Posts by Sap Displacement Methods
}

\author{
Evandro Teleginski ${ }^{1}$, Gilmara de Oliveira Machado ${ }^{1}$, Marcio Rogerio da Silva ${ }^{2}$, \\ Victor Almeida de Araujo ${ }^{3}$, Diogo Aparecido Lopes Silva ${ }^{4}$, André Luis Christoforo ${ }^{5, *}$, \\ Francisco Antonio Rocco Lahr ${ }^{6}$
}

\author{
${ }^{1}$ Department of Forestry, State University of Midwest (UNICENTRO), Irati, Brazil \\ ${ }^{2}$ Department of Materials Engineering (SMM), Engineering School of São Carlos of University of São Paulo (EESC/USP), São Carlos, \\ Brazil \\ ${ }^{3}$ Research Group LIGNO of UNESP-Itapeva, Department of Forest Sciences, School of Agriculture Luiz de Queiroz of University of São \\ Paulo (ESALQ/USP), Piracicaba, Brazil \\ ${ }^{4}$ Department of Production Engineering, Engineering School of São Carlos (EESC/USP), São Carlos, Brazil \\ ${ }^{5}$ Centre for Innovation and Technology in Composites (CITeC), Department of Civil Engineering (DECiv), Federal University of São \\ Carlos (UFSCar), São Carlos, Brazil \\ ${ }^{6}$ Department of Structures Engineering (SET), Engineering School of São Carlos of University of São Paulo (EESC/USP), São Carlos, \\ Brazil
}

\begin{abstract}
Timber from eucalyptus and pines trees used in contact with the ground requires preservative treatment to prolong their useful life under natural condition. To obtain resistant timber fence posts to xylophagous attack, this research aimed to evaluate the preservative treatment with CCB applied in Eucalyptus dunnii Maiden and Pinus taeda L woods by sap substitution method. We found that Eucalyptus and pine treated posts had equilibrium moisture content of $17.33 \% \pm$ 0.51 and $17.02 \% \pm 0.27$, respectively. The equilibrium moisture content was $10 \%$ higher for eucalyptus and $5 \%$ higher for pine than that for untreated fence post. The mean basic density was $438 \mathrm{~kg} / \mathrm{m}^{3} \pm 21$ and $395 \mathrm{~kg} / \mathrm{m}^{3} \pm 23$ respectively, and the porosity of both woods was about $59 \%$. Eucalyptus and pine wood presented high porosity and low density, which may promote a good impregnation of CCB preservative. The mean active ingredients of treated fence posts were $6.18 \mathrm{~kg}$ i.a $/ \mathrm{m}^{3} \pm$ 0.41 for eucalyptus and $5.88 \mathrm{~kg} \mathrm{i.a} / \mathrm{m}^{3} \pm 0.73$ for pine. Finally, the treated fence posts had a low cost. The average cost of treatment for eucalyptus and pine was US\$ 1.55 per meter \pm 0.14 and US $\$ 1.63$ per meter \pm 0.07 , respectively. This price can be even lower if the owners had the wood in their properties. In conclusion, the treatment reached the minimum requirement of $5 \mathrm{~kg}$ of active ingredient per cubic meter of treated timber with a low cost, being the fence post apt to be used directly in contact with the ground.
\end{abstract}

Keywords Treated wood, Sap replacement, Bio deterioration

\section{Introduction}

In Brazil, most eucalyptus and pine plantations are located in the South and Southeastern regions, near to the cellulose and paper mills as well as the steel foundries. They are fast growing species and can be harvested to use as fence posts. Eucalyptus and pine posts can be food source for various wood decay organisms and they cannot be used without preservative treatment $[1,2]$.

Untreated fence posts hardly exceed three years of durability under natural conditions. A low quality fence post required constant monitoring and replacement that it is not

* Corresponding author:

alchristoforo@yahoo.com.br (André Luis Christoforo)

Published online at http://journal.sapub.org/ijme

Copyright (C) 2015 Scientific \& Academic Publishing. All Rights Reserved always effective to small producers, so the use of treated wood may be the most affordable option especially in rural areas [3-4].

In order to inhibit deteriorations by xylophages, fence wood posts can be treated with CCB (borate solution of chromate copper). $\mathrm{CCB}$ is a preservative that react and become fix to the wood after treatment, being effective against all kind of xylophages and suitable for wood to be used in contact with the ground $[2,5,6]$.

CCB preservative can be applied by sap displacement or vacuum/pressure impregnation methods. Although pressure impregnation achieves fast result, the sap displacement method is more affordable cost and easier applicable method of treating fence posts. This method is widely used by agricultural employees in rural areas $[2,5,6]$.

In Sap displacement method, the sap of fresh wood is replaced by preservative. This treated wood has a 
considerably longer life; and, reportedly passed by technicians from Emater (Enterprise Technical Assistance and Rural Extension from Brazil), the treated CCB fence posts can exceed 15 years long $[2,5,6]$.

The main purpose of this research is to evaluate the chemical treatment of Eucalyptus dunnii MAIDEN and Pinus taeda L. fence posts with CCB preservative by sap substitution method. We estimated and compared the absorption time and the amount of CCB solution absorbed by wood to obtain the quantity of active ingredients for treated fence posts. Additionally, we also estimate the cost of treated posts.

\section{Material and Methods}

The experiment was conducted at a private property near the campus of the Midwest State University, in Irati city, Paraná state, Brazil. The geographical coordinates is $25^{\circ} 31^{\prime} 6.59^{\prime \prime} \mathrm{S} \times 50^{\circ} 39^{\prime} 22.94^{\prime \prime} \mathrm{O}$. The climate of this region is tempered. There are mild summers, no dry seasons and winters with occurrences of severe and frequent frosts.

We selected two species for the present investigation: Eucalyptus dunnii MAIDEN and Pinus taeda L. Four different trees of each species were used.

On the first day of February 2014, with a chainsaw Stihl ${ }^{\circledR} 170$ model, 4.5-year-old eucalyptus and 9-year-old pine trees were felled. Each trunk was crosscut in two to produce 8 posts by species. The top ends of each post were cut diagonally at approximately $45^{\circ}$ inclination in order to increase the contact area with the solution of CCB and also to increase water evaporation from the sap in the radial surface (Figure 1).

Each trunk tree was manually debarking with a metallic hammer. Debarked posts increase CCB preservative absorption because it allows the evaporation of the sap from the exposed wood surface. In addition, the wood surface was subjected to attrition with a wire brush to remove the vascular exchange layer and to allow better radial impregnation.

With a tape measure pinpoint accuracy, we measured the circumference of the base, the middle $(1.1 \mathrm{~m})$ and the top of the trunk. The diameters were tabulated in order to calculate

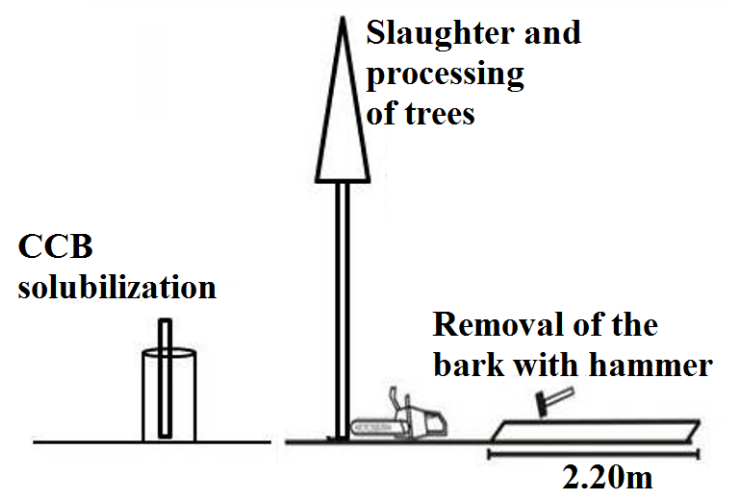

the volume of each posts, by Newton's method, expressed by Equation 1 [7], where $V$ is the volume in $\mathrm{m}^{3}, d_{i}$ is the diameter in $\mathrm{cm}, g$ is the cross-sectional area in $\mathrm{m}^{2}$. Also, $g_{l}$ is the cross-sectional area in $\mathrm{m}^{2}$ of the base, $g_{2}$ of the middle and $g_{3}$ of the top of the post, respectively. Table 1 present the values of diameters and volumes.

$$
V=\left(\frac{g_{1}+4 g_{2}+g_{3}}{6}\right) \cdot c \quad g_{i}=\frac{\pi \cdot d_{i}^{4}}{40000}
$$

Table 1. Diameters and volumes of eucalyptus and pine fence posts. Volume is calculated by Newton method

\begin{tabular}{c|c|c|c|c}
\hline \multicolumn{5}{c}{ Diameters and volumes of stakes } \\
\hline & $\begin{array}{c}\text { Base } \\
(\mathbf{c m})\end{array}$ & Center $\mathbf{( c m )}$ & Top $(\mathbf{c m})$ & Volume (m) \\
\hline Eucalip. 1 & 9.5 & 9.3 & 8.9 & 0.0150 \\
Eucalip. 2 & 9.5 & 9.2 & 8.9 & 0.0147 \\
Eucalip. 3 & 8.5 & 8.2 & 7.6 & 0.0116 \\
Eucalip. 4 & 7.9 & 7.3 & 6.8 & 0.0093 \\
\hline Pinus 1 & 8.9 & 8.2 & 7.9 & 0.0120 \\
Pinus 2 & 10.3 & 9.7 & 9.3 & 0.0164 \\
Pinus 3 & 8.9 & 8.5 & 8.2 & 0.0127 \\
Pinus 4 & 10.5 & 10.0 & 9.8 & 0.0175 \\
\hline
\end{tabular}

For the physical analysis, the wood was collected by cutting disks from the trunk and the disks were then cut into test-pieces. The moisture measurements were made on 8 blocks of wood $(2 \times 3 \times 5 \mathrm{~cm})$ per species. The blocks were weighed on a digital scale with precision of $0.001 \mathrm{~g}$. They were then dried in an oven, with air circulation, at temperature of $103^{\circ} \mathrm{C} \pm 2{ }^{\circ} \mathrm{C}$ until constant weight. The moisture content (MC) in a dry and wet basis are determined by Equation 2 and 3, respectively, where the initial mass of wet wood is $m_{i}$ and the dry mass of dry wood (at $0 \%$ moisture content) is $m_{s}$. [8].

$$
\begin{aligned}
M C_{d r y} & =\left(\frac{m_{i}-m_{s}}{m_{s}}\right) \cdot 100(\%) \\
M C_{\text {wet }} & =\left(\frac{m_{i}-m_{S}}{m_{i}}\right) \cdot 100(\%)
\end{aligned}
$$

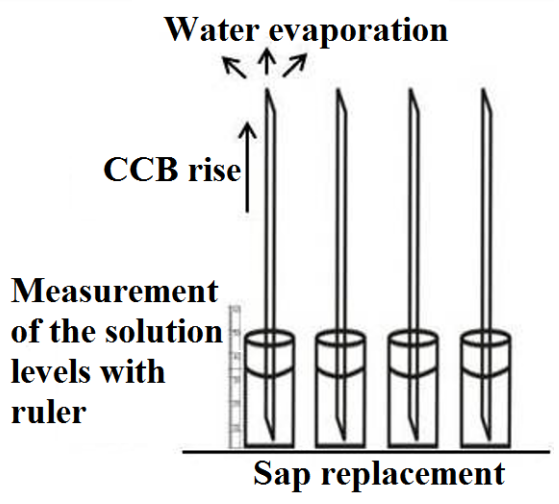

Figure 1. Schematic representation of experiment preparation 
To detect if the CCB application increase the hygroscopicity of wood, it was determined the equilibrium moisture content. Sixteen specimens were used with dimensions of $2 \mathrm{~cm} \times 3 \mathrm{~cm} \times 5 \mathrm{~cm}$. For each species (eucalyptus and pine) were produced four wooden specimens untreated and four wooden specimens treated with CCB preservative. Wood blocks remained 30 days in enclosed and ventilated area and it was subsequently stored for 20 days in a climate-controlled room, with air moisture and temperature control, in the Laboratory of Wood Properties at the Midwest State University, with temperature at $20^{\circ} \mathrm{C} \pm 2{ }^{\circ} \mathrm{C}$ and relative air moisture at $65 \%$ $\pm 5 \%$. The specimens were weighed and then kept in an oven at $103^{\circ} \mathrm{C} \pm 2{ }^{\circ} \mathrm{C}$ until weights stabilized. The moisture contents were calculated on a dry basis and also on a wet basis.

For density measurements, from the base of each post it was removed two test-pieces, totaling eight samples that having dimensions of $5 \mathrm{~cm} \times 2 \mathrm{~cm} \times 3 \mathrm{~cm}$ [8]. The test-pieces were immersed in water for the purpose of saturating the wood until constant weight. Then, the volumes were measured by the method of hydrostatic balance. After, the test-pieces were dried in an oven with air circulation with temperature at $103^{\circ} \mathrm{C} \pm 2$ until stabilizing the weights. The basic density ( $\left.\rho_{\text {bas }}\right)$ was obtained by the Equation 4 , where $m_{d}$ is the dried mass and $v_{s}$ is the saturated volume.

$$
\rho_{\text {bas }}=\frac{m_{d}}{v_{s}}
$$

The porosity of wood refers to empty volume fraction in the timber. To calculate the porosity $(\eta)$, it was used the Equation 5 [9], where the basic density $\left(\rho_{\text {bas }}\right)$ is expressed in $\mathrm{g} / \mathrm{cm}^{3}$ and the apparent density $\left(\rho_{\mathrm{ap}}\right)$ is in $\mathrm{g} / \mathrm{cm}^{3}$, with a moisture content of $U(\%)$. The $U(\%)$ moisture content for apparent density was measured too. This moisture content must be below of fiber saturation point (below 25\% moisture) so that there is not the presence of moisture in the lumen of the wood cell. The factor 0.685 is the specific volume of the wood (volume occupied by cell walls of the wood) in $\mathrm{cm}^{3} / \mathrm{g}$.

$$
\eta=1-\rho_{\text {bas }} \cdot\left(0.685+0.01 \cdot \frac{U(\%)}{\rho_{a p}}\right)
$$

To determine the percentage of late wood for Pinus taeda, the opposing faces of the wood discs had the diameters measured with a millimeter ruler precision in the radial direction, using the ratio of the major diameter to the minor diameter (Figure 2). With a pencil, they were demarcated the latewood bands that is darker than early wood. With a ruler were measured and noted the dimensions in millimeters of each latewood band. The average dimensions of latewood bands were divided by the average value of the total disk size that resulting in the percentage of late wood.

About the preparation of $\mathrm{CCB}$ solution, it was used two commercial kits with CCB water soluble, which was purchased from a store of agricultural products, (Figure 3 and Table 2). Each kit is formulated to prepare 100 liters of CCB solution. The formulation of these CCB kits follows the recommendation of the studies published by Embrapa Forests [10].

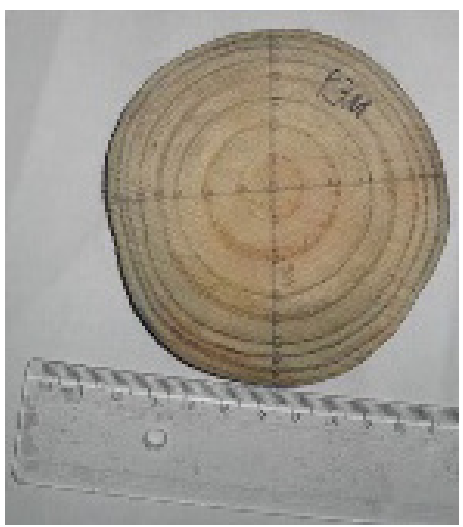

Figure 2. Demarcation and measurement of the latewood discs of Pinus taeda with 9.5 years old

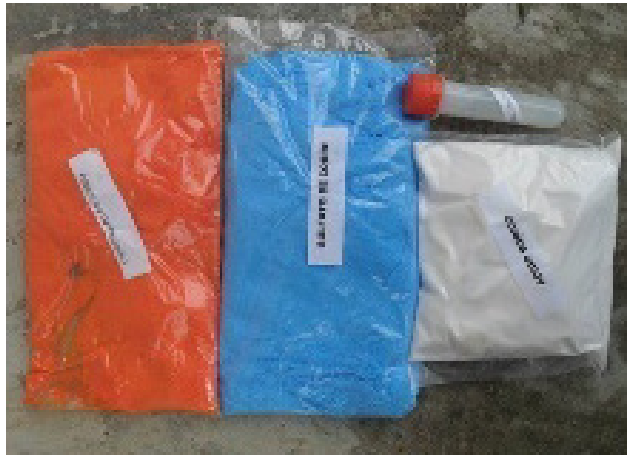

Figure 3. CCB Kit. In orange, sodium dichromate, in blue, copper sulfate and white, boric acid. The tube contains $25 \mathrm{ml}$ of glacial acetic acid

Table 2. CCB solution from commercial kit components

\begin{tabular}{cc}
\hline Components & Quantity \\
\hline Sodium dichromate & $900 \mathrm{~g}$ \\
Copper sulphate & $850 \mathrm{~g}$ \\
Boric acid & $620 \mathrm{~g}$ \\
Glacial acetic acid & $25 \mathrm{ml}$ \\
Water & $100 \mathrm{~L}$ \\
\hline Solution concentration $(\%)$ & 2.395
\end{tabular}

In a plastic drum, it was added 10 liters of water and 50 $\mathrm{ml}$ of glacial acetic acid. The acid was used to acidify the solution for increasing the power of water solubility and then minimize the formation of precipitates. In following, it was slowly added sodium dichromate, copper sulfate and boric acid, shaking them all with a wooden rod until complete solubilization.

In sap displacement methods, the fresh wood in its wet state are placed in a vessel with their top ends in a CCB solution. The sap evaporates from one end of the post as the preservative is drawn up to displace the sap.

For treatment of the fence posts, it was used eight drums of polyethylene with $25 \mathrm{~L}$ capacity each. The drums were graded to obtain the volume absorbed of preservative based 
on reading the level of the preservative solution, measured in centimeters, by a millimeter precision ruler of $60 \mathrm{~cm}$. For the calibration of each drum it was added $1 \mathrm{~L}$ of water volumes and recorded it in centimeters levels, obtaining a relation of $1.5 \mathrm{~cm}$ on the scale for each liter of preservative absorbed (Figure 4). In Table 3, it is stated the relationship between the volume and level of preservative solution.

Table 3. Ratio between liquid volume and level on the scale

\begin{tabular}{cc}
\hline Volume (L) & Level (cm) \\
\hline 1 & 1.5 \\
2 & 3 \\
3 & 4.5 \\
21 & 31.5 \\
22 & 33 \\
23 & 34.5 \\
\hline Average & 1.5 \\
\hline
\end{tabular}

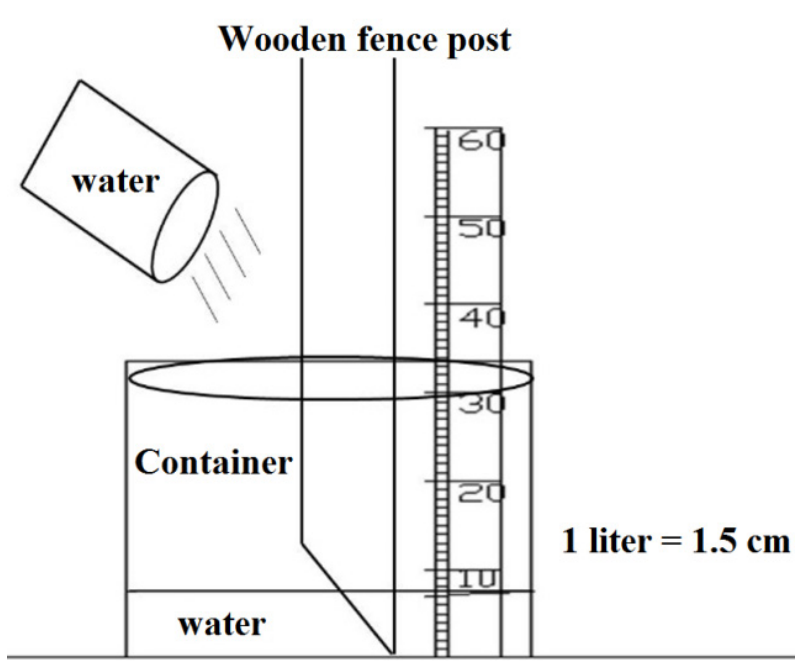

Figure 4. Schematic representation of the methodology used for volumetric graduation containers

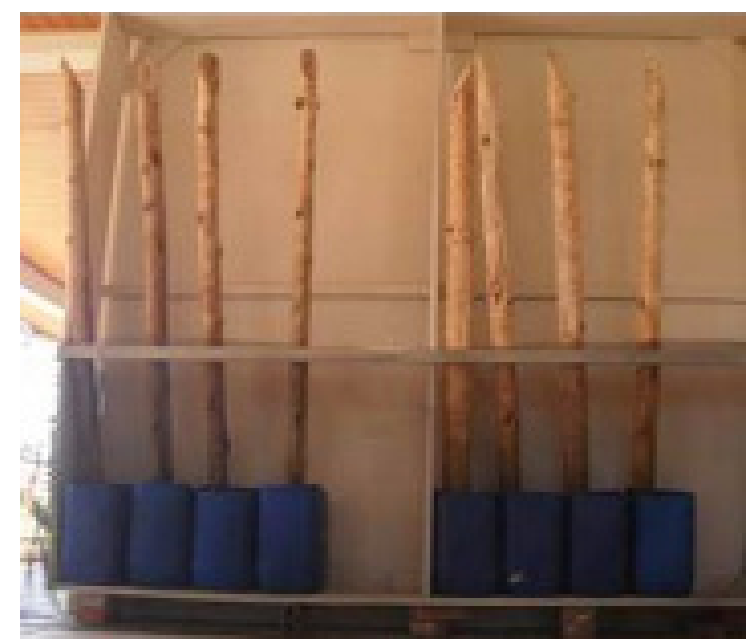

Figure 5. Experimental design for the sap replacement method. on the left, are the eucalyptus fence posts and on the right the pine fence posts

In each drum, it was added $1 \mathrm{~L}$ of the concentrated solution of $\mathrm{CCB}$ and then $19 \mathrm{~L}$ of water, $20 \mathrm{~L}$ total, to achieve the preservative concentration of $2.395 \%(\mathrm{~m} / \mathrm{v})$. Additionally, it was added about $100 \mathrm{ml}$ of vegetable oil in order to create a film on the water surface and prevent evaporation from the preservative solution. In each vessel it was placed freshly cut fence post without the barks in a vertical position into the preservative. The posts were submerged in CCB solution at the same vertical position of the tree trunk, to allow the sap flow in the same longitudinal direction of the tree (Figure 5).

Soon after the installation of fence posts into CCB preservative, the solution levels were recorded in centimeters with a millimeter precision ruler. Every 24 hours the solution levels were measured again. To obtain the volume absorbed daily, measurements were subtracted from one day to the other. The measurements in centimeters divided by the constant 1.5 resulted in the volume $\left(V_{\mathrm{CCB}}\right)$ of liters absorbed, according to the Equation 6. In equation 6, $P D L$ is the solution level of the previous day $(\mathrm{cm})$ and NDL is the next day solution level $(\mathrm{cm})$.

$$
v_{C C B}=\frac{2}{3} \cdot(P D L-N D L)
$$

When the level of the solution becomes lower, the container was again completed and the solution level was measured again. The posts were leaving in the preservative solution for seven days. After that, the position of the posts was reversed and it was dipping the top end of the posts into the preservative for more 7 days, to ensure a complete spread of the preservative. Again, it was measured the levels of the preservative solution until the fourteenth day.

After 14 days of treatment, the fence posts were removed from the preservative solution and stored in a warehouse for 40 days so that natural drying occurred and allowing the fixation of the preservative in the wood. After drying the wood, the chrome is already in the trivalent form, losing its harm oxidizing potential and making the manipulation of the wood safe. With the remaining of CCB solution, it was treated additional wood residues to avoid the solution storage.

The experimental design consisted of a CRD (completely randomized design), where each species was considered a treatment, and each fence post was considered a repeat. The same it was done with the wood test-pieces for the determination of density and moisture, with each species treatment and each specimen a repeat. The average absorption of each fence post was submitted to $F$ test to verify the homogeneity of variance and then the $t$ test for comparison of averages.

If the $\mathrm{F}$ test returned homogeneous variances, it would adopt that $t$ test assuming equal variances. If $F$ returned on heterogeneous variance test, it would take the t-test assuming variances not equivalent. This is a statistical processing method, which can detect differences between non-parametric data. The hypothesis $\mathrm{H}_{0}$ used was that the averages are equal and the hypothesis $\mathrm{H}_{1}$ was that the averages were different, at a 5\% confidence interval 
$(p \leq 0.05)$. If the value of "p" was greater than 0.05 , it would admit that there was no significance, accepting the null hypothesis $\mathrm{H}_{0}$, in other words the averages are statistically equal.

Statistical tests were run in Microsoft Excel 2010 program, with the "Data analysis" supplement. With means and their standard deviations it was calculated the coefficient of variation - $C v(\%)$, which represents the reproducibility of experimental data.

For boron distribution analysis, in the radial direction of the wood, the obtained values were tabulated in the form of factorial, with species factors (eucalyptus and pine) and the factor position (base, middle or top end of the posts). The factor analyzes were performed with the Statgraphics ${ }^{\circledR}$ Centurion program.

\section{Results and Discussions}

The moisture content means of untreated posts from freshly sawn wood at wet and dry basis are not significantly different between Eucalyptus and Pines [dry basis: 138,48\% $\pm 3,81$ vs. $137,13 \% \pm 5,69$, P-value $=0,58$; wet basis: $58,05 \%$ $\pm 0,67$ vs. $57,8 \% \pm 0,99$, P-value $=0,56]$, Table 4 .

The equilibrium moisture content of untreated and treated posts with CCB preservative, at wet and at dry basis, are not significantly different between Eucalyptus and Pines, Table 5 and Table 6.
Using the data from equilibrium moisture content at wet basis (Table 5), a factor analysis was performed with the factor-species (eucalyptus and pine) and the factor-treatment (no treatment and treatment with $\mathrm{CCB}$ preservative) (Table 6).

According to Table 6, there was no statistical difference in the equilibrium moisture content between the eucalyptus and pine species (P-value $=0.5998)$. However, there was statistical difference between untreated and treated wood $(\mathrm{P}$-value $=0.0000)$ as well as for the species-treatment interaction $(\mathrm{P}$-value $=0.0374)$.

The equilibrium moisture content was $10 \%$ higher in treated posts than in untreated posts for eucalyptus species [wet basis: $17.33 \% \pm 0.51$ vs. $15.61 \% \pm 0.11$, P-value $=0,00$ ] The same tendency happens with posts from pine wood, where the equilibrium moisture content was $5 \%$ higher in treated posts [wet basis: $17.02 \% \pm 0.27$ vs $16.1 \% \pm 0.31$, P-value $=0,00]$. Additionally, there are interactions between species used and preservative applied for all fence posts $($ Table $6, \mathrm{P}$-value $=0.0374)$. These results show that although the ANOVA was able to detect significant difference between treated and untreated fence posts, it was observed that the water-soluble $\mathrm{CCB}$, which has in its constitution salts, did not cause a significant increase in the hygroscopicity of the treated fence posts.

About the basic density of fence posts, the data are shown in Table 7.

Table 4. Initial moisture content of Eucalyptus dunnii and Pinus taeda for untreated fence posts

\begin{tabular}{|c|c|c|c|c|c|}
\hline Species & Repetition & Wet Weight (g) & Dry Weight $\left(103^{\circ} \mathrm{C}\right)(\mathrm{g})$ & Moisture dry basis (\%) & Moisture wet basis (\%) \\
\hline \multirow{8}{*}{ Eucalyptus } & 1 & 33.75 & 14.26 & 136.62 & 57.74 \\
\hline & 2 & 34.07 & 14.14 & 141.05 & 58.51 \\
\hline & 3 & 34.18 & 14.80 & 130.97 & 56.70 \\
\hline & 4 & 33.95 & 14.14 & 140.12 & 58.35 \\
\hline & 5 & 33.69 & 14.16 & 137.99 & 57.98 \\
\hline & 6 & 33.93 & 14.34 & 136.59 & 57.73 \\
\hline & 7 & 34.23 & 14.21 & 142.33 & 58.73 \\
\hline & 8 & 34.43 & 14.22 & 142.21 & 58.71 \\
\hline $\bar{x}$ and $S d$ & & & & $138.48 \pm 3.81$ & $58.05 \pm 0.67$ \\
\hline$C v(\%)$ & & & & 2.75 & 1.16 \\
\hline \multirow{8}{*}{ Pine } & 1 & 29.90 & 12.63 & 136.66 & 57.75 \\
\hline & 2 & 29.60 & 12.04 & 145.93 & 59.34 \\
\hline & 3 & 27.50 & 11.18 & 145.91 & 59.33 \\
\hline & 4 & 27.60 & 11.91 & 131.84 & 56.87 \\
\hline & 5 & 28.30 & 12.04 & 135.01 & 57.45 \\
\hline & 6 & 27.90 & 11.83 & 135.76 & 57.58 \\
\hline & 7 & 26.60 & 11.92 & 131.64 & 56.83 \\
\hline & 8 & 28.20 & 12.03 & 134.34 & 57.33 \\
\hline $\bar{x}$ and $S d$ & & & & $137.13 \pm 5.69$ & $57.8 \pm 0.99$ \\
\hline$C v(\%)$ & & & & 4.15 & 1.72 \\
\hline \multirow{2}{*}{$t$ Test } & & & & $\mathrm{t}=0.55$ & $\mathrm{~T}=0.58$ \\
\hline & & & & $P$-value $=0.58$ & $P$-value $=0.56$ \\
\hline
\end{tabular}

Data are from 8 posts for each species, where $\bar{x}$ is mean, $S d$ is standard deviation, and $C v$ is coefficient of variation. P-value by t-test, at $5 \%$ probability. 
Table 5. Equilibrium moisture content of Eucalyptus dunnii and Pinus taeda for untreated and treated fencing posts with CCB preservative

\begin{tabular}{|c|c|c|c|c|c|c|}
\hline Specie & Treatment & Repetitons & Wet Weight (g) & Dry Weight $\left(103^{\circ} \mathrm{C}\right)(\mathrm{g})$ & Moisture dry basis (\%) & Moisture wet basis (\%) \\
\hline \multirow{11}{*}{ Eucalyptus } & \multirow{6}{*}{ Untreated } & 1 & 16.942 & 14.296 & 18.51 & 15.62 \\
\hline & & 2 & 16.497 & 13.934 & 18.39 & 15.54 \\
\hline & & 3 & 15.814 & 13.318 & 18.74 & 15.78 \\
\hline & & 4 & 14.102 & 11.913 & 18.37 & 15.52 \\
\hline & & $\bar{x}$ and $S d$ & & & $18.5 \pm 0.16$ & $15.61 \pm 0.11$ \\
\hline & & $C v(\%)$ & & & 0.91 & 0.77 \\
\hline & \multirow{6}{*}{ Treated } & 1 & 18.494 & 15.217 & 21.54 & 17.72 \\
\hline & & 2 & 18.062 & 15.059 & 19.94 & 16.63 \\
\hline & & 3 & 17.077 & 14.05 & 21.54 & 17.73 \\
\hline & & 4 & 15.732 & 13.017 & 20.86 & 17.26 \\
\hline & & $\bar{x}$ and $S d$ & & & $20.96 \pm 0.75$ & $17.33 \pm 0.51$ \\
\hline \multirow{13}{*}{ Pinus } & & $C v(\%)$ & & & 3.61 & 3.00 \\
\hline & \multirow{6}{*}{ Untreated } & 1 & 11.532 & 9.681 & 19.12 & 16.05 \\
\hline & & 2 & 13.911 & 11.628 & 19.63 & 16.41 \\
\hline & & 3 & 10.55 & 8.895 & 18.61 & 15.69 \\
\hline & & 4 & 14.359 & 12.024 & 19.42 & 16.26 \\
\hline & & $\bar{x}$ and $S d$ & & & $19.19 \pm 0.44$ & $16.1 \pm 0.31$ \\
\hline & & $C v(\%)$ & & & 2.32 & 1.95 \\
\hline & \multirow{6}{*}{ Treated } & 1 & 12,311 & 10,225 & 20.40 & 16.94 \\
\hline & & 2 & 14.411 & 12.001 & 20.08 & 16.72 \\
\hline & & 3 & 15.979 & 13.201 & 21.04 & 17.39 \\
\hline & & 4 & 10.887 & 9.029 & 20.58 & 17.07 \\
\hline & & $\bar{x}$ and $S d$ & & & $20.52 \pm 0.40$ & $17.02 \pm 0.27$ \\
\hline & & Cv (\%) & & & 1.96 & 1.62 \\
\hline
\end{tabular}

Table 6. ANOVA for factorial analysis of equilibrium moisture content at wet basis

\begin{tabular}{cccccc}
\hline Source & Sum of Squares & DF & Mean Square & F-Ratio & P-value \\
\hline A: Specie & 0.0333063 & 1 & 0.0333063 & 0.29 & 0.5998 \\
B: Treatment & 7.00926 & 1 & 7.00926 & 61.11 & 0.0000 \\
AB: Interaction & 0.628056 & 1 & 0.628056 & 5.48 & 0.0374 \\
Residual & 1.37648 & 12 & 0.114706 & & \\
Total & 9.04709 & 15 & & & \\
\hline
\end{tabular}

\section{Absorption Curves - Eucalyptus dunnii}

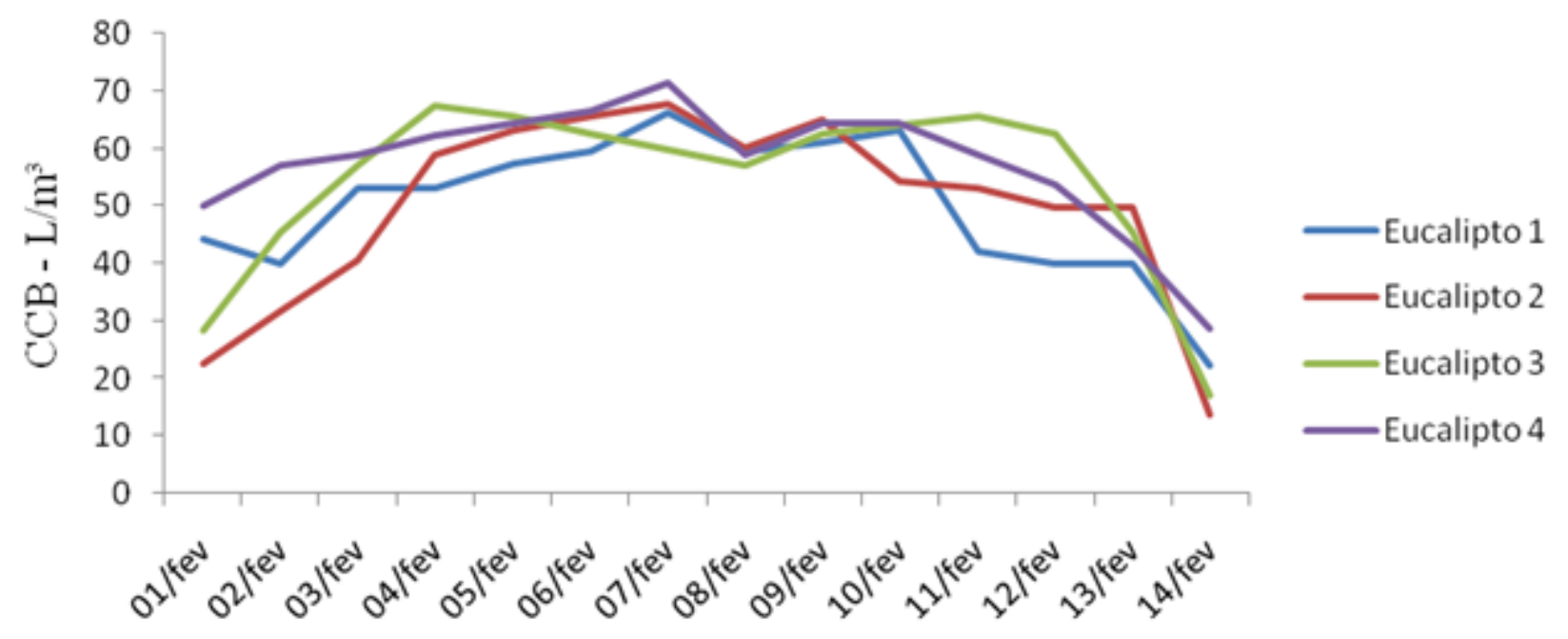

Figure 6. Absorption curves of CCB preservative for Eucalyptus dunnii 
Table 7. Basic density of Eucalyptus dunnii and Pinus taeda

\begin{tabular}{|c|c|c|c|c|c|}
\hline Species & Repetition & Wet Weight (g) & Saturated Volume & Basic density $\left(\mathrm{g} / \mathrm{cm}^{3}\right)$ & Basic density $\left(\mathrm{kg} / \mathrm{m}^{3}\right)$ \\
\hline \multirow{8}{*}{ Eucalyptus } & 1 & 13.132 & 31.2 & 0.421 & 421 \\
\hline & 2 & 15.274 & 32.2 & 0.473 & 473 \\
\hline & 3 & 13.243 & 31.8 & 0.416 & 416 \\
\hline & 4 & 14.34 & 31.7 & 0.452 & 452 \\
\hline & 5 & 14.143 & 31.5 & 0.449 & 449 \\
\hline & 6 & 12.786 & 30.9 & 0.414 & 414 \\
\hline & 7 & 14.233 & 31.4 & 0.453 & 453 \\
\hline & 8 & 12.987 & 30.7 & 0.423 & 423 \\
\hline $\bar{x}$ and $S d$ & & & & $0.437 \pm 0.021$ & $437 \pm 21$ \\
\hline $\mathrm{Cv}(\%)$ & & & & 4.99 & 4.99 \\
\hline \multirow{8}{*}{ Pine } & 1 & $11 . .56$ & 31.6 & 0.365 & 365 \\
\hline & 2 & 12.012 & 30.7 & 0.392 & 392 \\
\hline & 3 & 11.988 & 31.2 & 0.384 & 384 \\
\hline & 4 & 12.132 & 30.8 & 0.394 & 394 \\
\hline & 5 & 13.219 & 330.7 & 0.431 & 431 \\
\hline & 6 & 13.479 & 31.1 & 0.433 & 433 \\
\hline & 7 & 11.873 & 30.9 & 0.384 & 384 \\
\hline & 8 & 12.328 & 31.2 & 0.395 & 395 \\
\hline $\bar{x}$ and $S d$ & & & & $0.395 \pm 0.023$ & $395 \pm 23$ \\
\hline$C v(\%)$ & & & & 5.87 & 5.87 \\
\hline
\end{tabular}

Table 8. Basic density ( $\left.\rho_{\text {bas }}\right)$, apparent density $\left(\rho_{\text {ap }} 14 \%\right)$ at $14 \%$ of moisture content, and porosity of pine and eucalyptus woods

\begin{tabular}{cccc}
\hline Species & $\boldsymbol{\rho}_{\text {bas }}\left(\mathbf{k g} / \mathbf{m}^{\mathbf{3}}\right)$ & $\begin{array}{c}\boldsymbol{\rho}_{\text {ap 14\% }} \\
\left(\mathbf{k g} / \mathbf{m}^{3}\right)\end{array}$ & $\begin{array}{c}\text { Porosity } \\
(\mathbf{\%})\end{array}$ \\
\hline Pinus $(\bar{x}$ and $S d)$ & $395 \pm 23$ & $421 \pm 64$ & 59.807 \\
Eucalipto $(\bar{x}$ and $S d)$ & $437 \pm 21$ & $556 \pm 21$ & 59.062 \\
\hline
\end{tabular}

Table 9. Dimensions of discs and percentage of late wood in Pinus taeda

\begin{tabular}{|c|c|c|c|c|}
\hline Repetition & Position & $\begin{array}{l}\text { Diameter } \\
(\mathbf{c m})\end{array}$ & $\begin{array}{c}\text { Latewood } \\
(\mathrm{mm})\end{array}$ & $\begin{array}{c}\text { Latewood } \\
(\%)\end{array}$ \\
\hline & Base & 9.7 & 14.50 & 14.95 \\
\hline \multirow[t]{3}{*}{1} & Center & 9.6 & 13.13 & 13.67 \\
\hline & Tip & 9.4 & 12.38 & 13.16 \\
\hline & Base & 8.4 & 11.00 & 13.10 \\
\hline \multirow[t]{3}{*}{2} & Center & 8.4 & 10.13 & 12.05 \\
\hline & Tip & 7.6 & 10.63 & 13.98 \\
\hline & Base & 9.65 & 14.00 & 14.51 \\
\hline \multirow[t]{3}{*}{3} & Center & 9.2 & 13.75 & 14.95 \\
\hline & Tip & 9.05 & 11.38 & 12.57 \\
\hline & Base & 8.55 & 9.00 & 10.53 \\
\hline \multirow[t]{4}{*}{4} & Center & 8.3 & 8.13 & 9.79 \\
\hline & Tip & 7.9 & 9.75 & 12.34 \\
\hline & & & $\bar{x}$ and $S d$ & $\begin{array}{c}12.96 \pm \\
1.63\end{array}$ \\
\hline & & & $C v(\%)$ & 12.57 \\
\hline
\end{tabular}

The mean of basic density was $437 \mathrm{~kg} / \mathrm{m}^{3} \pm 21$ and 395 $\mathrm{kg} / \mathrm{m}^{3} \pm 23$ for eucalyptus and the pine wood, respectively.
Table 8 shows also the results of wood porosity calculation for eucalyptus and pine woods.

It is observed in Table 8 that the porosity values for pine and eucalyptus are approximately 59\%. These values show that both wood presents high porosity, which may promote a good impregnation of CCB preservative into wood.

Table 10. Daily absorption of CCB solution for Eucalyptus

\begin{tabular}{c|c|c|c|c}
\hline \multicolumn{5}{c}{ Repetitions $\left(\mathbf{L} / \mathbf{m}^{3}\right)$} \\
\hline Date & Eucalipto 1 & Eucalipto 2 & Eucalipto 3 & Eucalipto 4 \\
\hline $01 \mathrm{feb}$ & 44.24 & 22.63 & 28.50 & 49.93 \\
$02 \mathrm{feb}$ & 39.81 & 31.68 & 45.59 & 57.06 \\
$03 \mathrm{feb}$ & 53.08 & 40.74 & 56.99 & 58.85 \\
$04 \mathrm{feb}$ & 53.08 & 58.84 & 67.48 & 62.05 \\
$05 \mathrm{feb}$ & 57.50 & 63.37 & 65.61 & 64.19 \\
$06 \mathrm{feb}$ & 59.72 & 65.62 & 62.69 & 66.33 \\
$07 \mathrm{feb}$ & 66.35 & 67.89 & 59.84 & 71.26 \\
$08 \mathrm{feb}$ & 59.72 & 60.29 & 56.99 & 58.85 \\
$09 \mathrm{feb}$ & 61.26 & 65.18 & 62.69 & 64.19 \\
$10 \mathrm{feb}$ & 63.42 & 54.31 & 64.12 & 64.19 \\
$11 \mathrm{feb}$ & 42.03 & 53.18 & 65.53 & 58.85 \\
$12 \mathrm{feb}$ & 39.81 & 49.79 & 62.69 & 53.50 \\
$13 \mathrm{feb}$ & 39.81 & 49.79 & 45.59 & 42.80 \\
$14 \mathrm{feb}$ & 22.12 & 13.58 & 17.10 & 28.53 \\
\hline Sum & 701.97 & 696.88 & 761.41 & 800.58 \\
\hline Cubage (m $\left.{ }^{3}\right)$ & 0.0151 & 0.0147 & 0.0117 & 0.0093 \\
\hline
\end{tabular}

In the Table 9 are found the percentage values of the late wood Pinus taeda. 
Table 11. Daily absorption of CCB solution for Pinus taeda

\begin{tabular}{ccccc}
\hline \multicolumn{5}{c}{ Repetitions $\left(\mathbf{L} / \mathbf{m}^{3}\right)$} \\
\hline Date & Pinus 1 & Pinus 2 & Pinus 3 & Pinus 4 \\
\hline 01 feb & 27.78 & 32.37 & 36.55 & 30.37 \\
02 feb & 38.89 & 44.50 & 52.21 & 45.55 \\
03 feb & 55.55 & 47.33 & 62.65 & 49.35 \\
04 feb & 61.11 & 48.55 & 62.65 & 45.55 \\
05 feb & 65.73 & 56.64 & 65.26 & 49.35 \\
06 feb & 66.66 & 56.64 & 62.65 & 49.35 \\
07 feb & 61.11 & 52.59 & 57.43 & 53.14 \\
08 feb & 61.11 & 48.55 & 57.43 & 53.14 \\
09 feb & 66.66 & 52.59 & 67.88 & 49.35 \\
10 feb & 66.66 & 52.59 & 62.65 & 49.35 \\
11 feb & 61.11 & 48.55 & 57.43 & 45.55 \\
12 feb & 58.33 & 44.50 & 53.99 & 45.55 \\
13 feb & 55.55 & 28.32 & 46.99 & 37.96 \\
14 feb & 27.75 & 20.23 & 41.77 & 18.98 \\
\hline Sum & 773.98 & 633.96 & 787.57 & 622.54 \\
\hline Cubage (m $\left.{ }^{3}\right)$ & 0.0120 & 0.0165 & 0.0128 & 0.0176 \\
\hline
\end{tabular}

The pine wood is composed by only $12.96 \% \pm 1,63$ of latewood. The predominance of juvenile wood improves the absorption of preservative because it promotes a good diffusion into the surrounding tissues and the preserving salts can be fixed in the cells.

The volume of CCB consumed per cubic meter of treated wood, it is shown in Table 10, Table 11, Figures 6 and Figure 7.

In both treatments, from first day to 4 February, the absorption of the CCB preservative increase fast, after that stabilizing until 7 February. On February 7, the positions of the fence posts in the preservative solution were reversed, at this time there was a small decrease of the absorption. Then, from 08 to 10 February the absorption returned to increase and after 11 and 14 February the curve returned to decline.

Based on the atomic weights of each component of CCB preservative, the active ingredients were calculated, Table 12.

According to Table 12, in each CCB kit there is $835.68 \mathrm{~g}$ of active ingredients represented by chromium in the form of $\mathrm{CrO}_{3}$. The copper is represented by $\mathrm{CuO}$ and boron by $\mathrm{B}$. There are $35.26 \%$ active ingredients per CCB kit.

Using the percentage of the active ingredients in the preservative solution for each fence post, Table 13 was constructed; where the CCB volumes $\mathrm{L} / \mathrm{m}^{3}$ were transformed in $\mathrm{kg} / \mathrm{m}^{3}$ (kilograms per cubic meter of $\mathrm{CCB}$ treated wood).

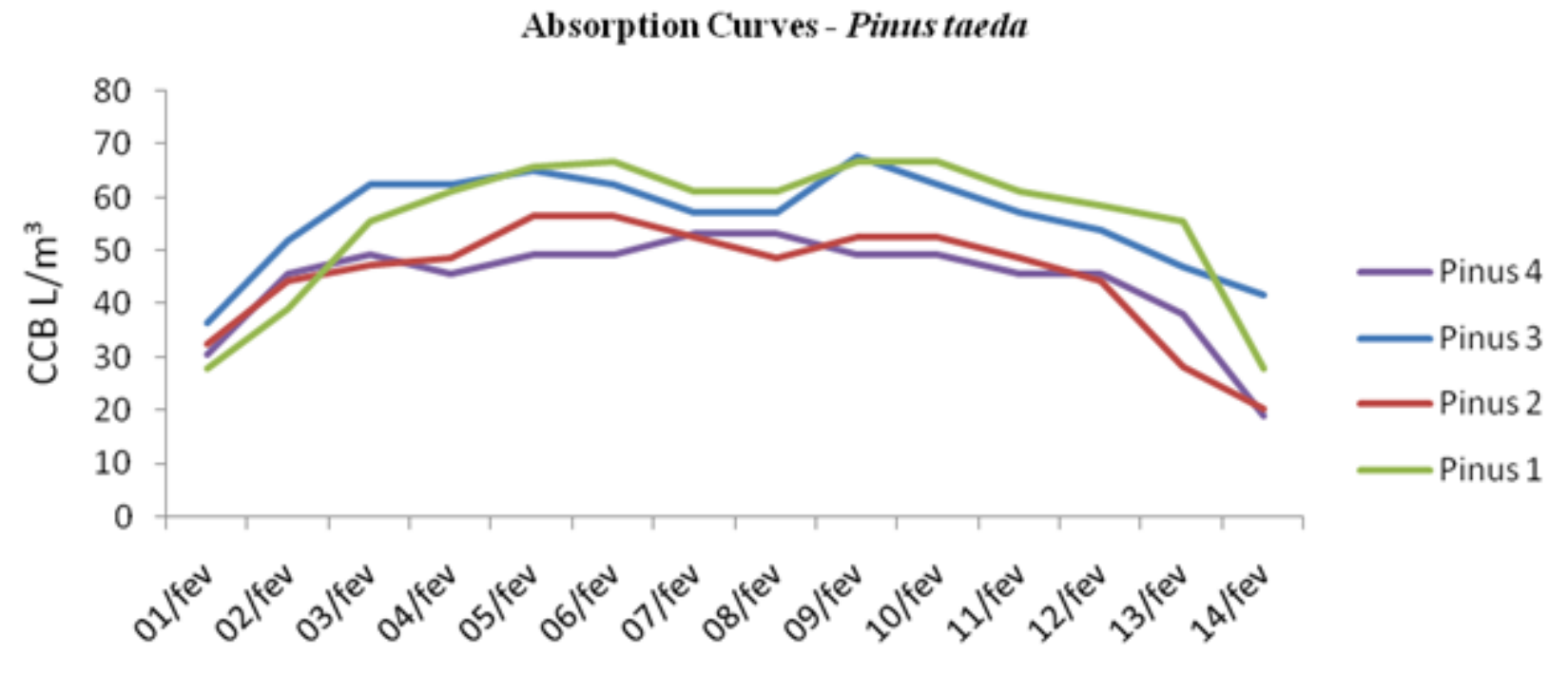

Figure 7. Absorption curves for Pinus taeda

Table 12. Relationship among CCB kit components and their respective active ingredients

\begin{tabular}{|c|c|c|c|c|c|c|c|c|}
\hline CCB Component & $\begin{array}{c}\text { Weight } \\
\text { Kg/kit CCB }\end{array}$ & $\mathbf{C F}$ & $\mathrm{g} / \mathrm{mol}$ & $\mathbf{A C}$ & $\mathrm{g} / \mathrm{mol}$ & $\mathrm{AC}(\%)$ & $\mathrm{AC}(\mathrm{Kg} / \mathrm{kit} \mathrm{CCB})$ & $\mathrm{AC}(\mathrm{g} / \mathrm{L})$ \\
\hline SD & $900 \mathrm{~g}$ & $\mathrm{Na}_{2} \mathrm{Cr}_{2} \mathrm{O}_{7} 2 \mathrm{H}_{2} \mathrm{O}$ & 298 & $\mathrm{CrO}_{3}$ & 100 & 33.56 & 302.01 & 3.02 \\
\hline $\mathrm{CS}$ & $850 \mathrm{~g}$ & $\mathrm{CuSO}_{4}$ & 159.5 & $\mathrm{CuO}$ & 79.5 & 49.84 & 423.67 & 4.24 \\
\hline \multirow[t]{3}{*}{ BA } & $620 \mathrm{~g}$ & $\mathrm{H}_{3} \mathrm{BO}_{3}$ & 62 & $\mathrm{~B}$ & 11 & 17.74 & 110.00 & 1.10 \\
\hline & & & & & & Sum & $835.68 \mathrm{~g}$ & $8.36 \mathrm{~g} / \mathrm{L}$ \\
\hline & & & & & & $\mathrm{AC}$ & & 35.26 \\
\hline
\end{tabular}


Table 13. Impregnation of CCB preservative and $\mathrm{CCB}$ active ingredients for each treated post

\begin{tabular}{ccccc}
\hline Specie & Cubage & CCB solution $\left(\mathbf{L} / \mathbf{m}^{3}\right)$ & CCB soluble $\left(\mathbf{k g} / \mathbf{m}^{\mathbf{3}}\right)$ & AC $\left(\mathbf{k g} / \mathbf{m}^{\mathbf{3}}\right)$ \\
\hline Eucalipto 1 & 0.0151 & 701.97 & 16.64 & 5.87 \\
Eucalipto 2 & 0.0147 & 696.88 & 16.52 & 5.82 \\
Eucalipto 3 & 0.0117 & 761.41 & 18.05 & 6.36 \\
Eucalipto 4 & 0.0093 & 800.58 & 18.97 & 6.69 \\
\hline Pinus 1 & 0.0120 & 773.98 & 18.34 & 6.47 \\
Pinus 2 & 0.0165 & 633.96 & 15.02 & 5.30 \\
Pinus 3 & 0.0128 & 787.57 & 18.67 & 6.58 \\
Pinus 4 & 0.0176 & 622.54 & 14.75 & 5.20 \\
\hline $\bar{x}$ and $S d$ [Eucalyptus] & 0.0127 & $740.21 \pm 49.77$ & $17.54 \pm 1.17$ & $6.18 \pm 0.41$ \\
\hline $\bar{x}$ and $S d$ [Pine] & 0.0147 & $704.50 \pm 88.35$ & $16.69 \pm 2.09$ & $5.88 \pm 0.73$ \\
\hline $\mathrm{t}$ test & & $\mathrm{t}=0.704 ;$ P-value $=0.507$ & $\mathrm{t}=0.704 ;$ P-value $=0.507$ & $\mathrm{t}=0.704 ; \mathrm{P}-\mathrm{value}=0.507$ \\
\hline$C v(\%)$ [Eucalyptus] & & 6.72 & 6.72 & 6.72 \\
\hline$C v(\%)$ Pine] & & 12.54 & 12.54 & 12.54 \\
\hline
\end{tabular}

Data are from 4 posts for each species, where $\bar{x}$ is mean, $S d$ is standard deviation, and $C v$ is coefficient of variation. AC is the active ingredients. P-value by t-test, at $5 \%$ probability

Table 14. Yield and cost of treated fence posts

\begin{tabular}{|c|c|c|c|c|c|c|c|}
\hline Species & Cubage $\left(\mathbf{m}^{3}\right)$ & $\mathrm{CCB}\left(\mathrm{L} / \mathrm{m}^{3}\right)$ & $\mathbf{m}^{3} / \mathbf{k i t}$ & Posts/kit & R\$/Post & Wood (R\$) & Total (R\$) \\
\hline Eucalyptus 1 & 0.0151 & 701.97 & 0.14 & 9.45 & 6.88 & 4.40 & 11.28 \\
\hline Eucalyptus 2 & 0.0147 & 696.88 & 0.14 & 9.74 & 6.67 & 4.40 & 11.07 \\
\hline Eucalyptus 3 & 0.0117 & 761.41 & 0.13 & 11.23 & 5.79 & 4.40 & 10.19 \\
\hline Eucalyptus 4 & 0.0093 & 800.58 & 0.12 & 13.36 & 4.86 & 4.40 & 9.26 \\
\hline Pine 1 & 0.0120 & 773.98 & 0.13 & 10.77 & 6.04 & 4.40 & 10.44 \\
\hline Pine 2 & 0.0165 & 623.03 & 0.16 & 9.74 & 6.67 & 4.40 & 11.07 \\
\hline Pine 3 & 0.0128 & 787.57 & 0.13 & 9.94 & 6.54 & 4.40 & 10.94 \\
\hline Pine 4 & 0.0176 & 622.54 & 0.16 & 9.15 & 7.11 & 4.40 & 11.51 \\
\hline $\bar{x} \pm S d$ [Eucalyptus] & 0.0127 & 740.21 & $0.14 \pm 0.008$ & $10.94 \pm 1.78$ & $6.05 \pm 0.92$ & 4.40 & $10.45 \pm 0.92$ \\
\hline $\bar{x} \pm S d[$ Pine $]$ & 0.0147 & 701.78 & $0.14 \pm 0.018$ & $9.89 \pm 0.66$ & $6.58 \pm 0.44$ & 4.40 & $10.98 \pm 0.44$ \\
\hline \multirow{2}{*}{$\mathrm{t}$ test } & & & $\mathrm{t}=0.84$ & $\mathrm{t}=1.09$ & $\mathrm{t}=1.05$ & & $\mathrm{t}=1.05$ \\
\hline & & & $\mathrm{p}=0.43$ & $\mathrm{p}=0.31$ & $\mathrm{p}=0.33$ & & $\mathrm{p}=0.33$ \\
\hline $\mathrm{Cv}(\%)$ [Eucalyptus] & & & 6.62 & 16.35 & 15.22 & & 8.81 \\
\hline $\mathrm{Cv}(\%)$ [Pine] & & & 13.01 & 6.76 & 6.68 & & 4.01 \\
\hline
\end{tabular}

The mean active ingredient of treated fence post was 6.18 $\mathrm{kg} \mathrm{i.a} / \mathrm{m}^{3} \pm 0.41$ for eucalyptus and $5.88 \mathrm{~kg} \mathrm{i.a} / \mathrm{m}^{3} \pm 0.73$ for pine. According to Torres et al. [11], the quantity of active ingredient range from $5-16 \mathrm{~kg}$ i.a. $/ \mathrm{m}^{3}$. Barillari [12] tested four species of pine (P. kesyia, P. oocarpa, P. elliottii, and P. hondurensis) under natural condition where the fence posts received retention levels of CCB from $4.08 \mathrm{~kg}$ i.a. $/ \mathrm{m}^{3}$ to 10 , $60 \mathrm{~kg}$ i.a. $/ \mathrm{m}^{3}$. For smaller retention rates, the fence post was preserved without any xylophages attack for 21 years. Barillari [12] still monitoring the experiment and they estimated that this treated posts may be in service conditions for 30 years.

Based on the absorption and impregnation of $\mathrm{CCB}$, it was calculated the yield of each kit and the cost of treatment for each fence post, according to Table 14 . To calculate the $\mathrm{m}^{3}$ of treated wood per kit, the value 100 was divided (number of gallons per kit CCB) for the amount of $\mathrm{L} / \mathrm{m}^{3}$ absorbed. To determine the number of treated fence posts per kit, the yield value in $\mathrm{m}^{3} / \mathrm{kit}$ was divided by the scaling of each repetition.

Table 14 presents the cost in Reais (Brazilian money), we used the conversion of 1 Dollar $=3,06$ Reais. Then, the cost of each CCB kit was R $\$ 65.00$ (US\$ 21.24). Considering purchases in small quantities, the wood is sold in Irati city, Paraná state for R\$ 2.00 (US\$ 0.65) per meter of untreated post. Eucalyptus and pine wood have the same price. Then, each untreated post of $2.20 \mathrm{~m}$ costs R $\$ 4.40$ (US\$ 1.44). If the producers already have the wood in their property, the cost of each treated fence post will be $\mathrm{R} \$ 6.05 \pm 0.92$ (US\$ 1.98) for eucalyptus and R $\$ 6.58 \pm 0.44$ (US\$ 2.15) 
for pine. If the wood need to be purchased, the mean cost for each treated fence post is R $\$ 10.45 \pm 0.92$ (US\$ $3.42 \pm$ 0,30 ) for eucalyptus and R $\$ 10.98 \pm 0.44$ (US\$ $3.59 \pm 0,14$ ) for pine. The calculus per meter, in dollar, of treated post wood for eucalyptus and pine is respectively US\$ 1.55 per meter \pm 0.14 and US $\$ 1.63$ per meter \pm 0.07 . It is a low cost preservative treatment by an ease process.

\section{Conclusions}

We conclude that CCB preservative treatment by sap displacement methods produce treated fence post with good quality and low cost, as follow shown.

Eucalyptus and pine treated post has equilibrium moisture content, in wet basis, of $17,33 \% \pm 0.51$ and $17,02 \% \pm 0.27$, respectively. The $\mathrm{CCB}$ preservative treatment interferes in the equilibrium moisture content of wood that is $10 \%$ higher for eucalyptus and $5 \%$ higher for pine. Then, CCB preservative does not significantly increase the hygroscopicity of treated fence posts.

The mean basic density is $438 \mathrm{~kg} / \mathrm{m}^{3} \pm 21$ and $395 \mathrm{~kg} / \mathrm{m}^{3}$ \pm 23 , and the porosity of both woods is about $59 \%$. Both wood presents high porosity and low density, which may promote a good impregnation of CCB preservative.

The predominance of juvenile wood in pine wood, about $87 \%$, may improve the absorption of preservative because it promotes a good diffusion into the surrounding tissues and the preserving salts can be fixed in the cells.

The mean active ingredient of treated fence post was 6.18 $\mathrm{kg}$ i.a $/ \mathrm{m}^{3} \pm 0.41$ for eucalyptus and $5.88 \mathrm{~kg} \mathrm{i.a} / \mathrm{m}^{3} \pm 0.73$ for pine. According to the scientific literature, the quantity of active ingredient range from 5 to $16 \mathrm{~kg}$ i.a. $/ \mathrm{m}^{3}$ of treated wood. Then, the treated posts provide a good protection against xylophages attack under natural condition.

Finally, the treated fence posts have a low cost. The average cost of treatment for eucalyptus and pine are respectively US\$ 1.55 per meter \pm 0.14 and US\$ 1.63 per meter \pm 0.07 . This price can be lower if the owners have the wood in their properties. The Eucalyptus and pine wood is sold (in Irati city, Paraná state, Brazil) for US\$ 0.65 per meter of untreated post. Additionally, the treatment of wood in local using can also be an effectively way to rural development, where the sale of treated wood could add value to timbers for the owner and even create jobs.

\section{REFERENCES}

[1] Machado, G. O.; Cookson, L; Christoforo, A. L.; Polito, W L; Silva, M. R.; Calil Jr, C; Lahr, F. A. R. Wood preservation based on Neem oil: evaluation of fungicidal and termiticidae effectiveness. Forest Products Journal, v. 63, p. 202-206, 2013

[2] Lepage, E. S. Manual de preservação de madeiras. São Paulo, IPT, 2v, 1986.

[3] Cassens, D. L. Selection and use of preservative: treated Wood. Madison, Forest Products Society, 104p., 1995.

[4] Ramos, I. E. C.; Paes, J. B.; Sobrinho, D. W. De F.; Santos, G. J. C. Eficiência do CCB na resistência da madeira de algaroba (Prosopisjuliflora (Sw.) D.C.) em ensaio de apodrecimento acelerado. Revista Àrvore, Viçosa-MG, v. 30, n. 5, p.811-820, 2006.

[5] Przybysz, M.; Machado, G. O.; Christoforo, A. L.; Silva, M.R.; Calil Jr, C. Resistência biológica a fungos xilófagos da madeira de Pinus oocarpa termorretificada. Revista Madeira, Arquitetura e Engenharia, v. 14, p. 25-32, 2013.

[6] Icimoto, F. H.; Ferro, F. S.; Varanda, L. D.; Souza, A. M.; Almeida, D. H.; Christoforo, A. L.; Lahr, F. A. R. Physical and mechanical properties of Paricá wood species treated with CCB preservative. International Journal of Materials Engineering, v. 3, n.4, p.82-86, 2013.

[7] Machado, S. A.; Figueiredo Filho, A. Dendrometria. Guarapuava, Unicentro, 316 p., 2009.

[8] Associação Brasileira de Normas Técnicas - ABNT - NBR 7190. Projeto de estruturas de madeira. Rio de janeiro, 107 p., 1997.

[9] Siau, J.F. Flow in wood. Syracuse, Syracuse University Press, 1971. $131 \mathrm{p}$.

[10] Magalhães, W. L. E.; Pereira, J. C. D. Método de substituição de seiva para preservação de mourões. Colombo: Embrapa Florestas, Comunicado Técnico, 97, 5 p., 2003.

[11] Torres, P.M. Arruda; Paes, J. B.; Filho, J. A. De Lira; Nascimento, J. W. B. Tratamento preservativo da madeira juvenil de Eucalyptus camaldulensis Dehnh. pelo método de substituição de seiva. Revista Cerne. 17 v. abril-junho, 2011, p. 275-282.

[12] Barillari, C.T. Durabilidade da madeira do gênero Pinus tratada com preservantes: avaliação em campo de apodrecimento. 2002. 68 p. Dissertação (Mestrado). Escola Superior de Agricultura Luiz de Queiroz, Universidade de São Paulo. Piracicaba. 2002. 